\title{
Modelling of selected hydrodynamic and hydrochemical parameters of a geothermal water system: an example of Cieplice therapeutic waters
}

\author{
Elżbieta Liber-Makowska ${ }^{1}$ D $\cdot$ Barbara Kiełczawa $^{1}$
}

Received: 31 May 2019 / Accepted: 27 April 2020 / Published online: 7 June 2020

(c) The Author(s) 2020

\begin{abstract}
Article presents results of long-period observations made in the most interesting and perspective geothermal area of Poland. Moreover, Cieplice is one of the oldest spa resort in Poland where thermal waters are used for treating purposes for centuries. That is the only one region in Poland with geothermal waters in granitic rocks and this can be interesting for international readers. The region of Jelenia Góra-Cieplice has been considered a prospective area of geothermal water occurrence for many years. The earliest evidence of balneological use of these waters dates from the thirteenth century. Currently, they are being used for therapeutic purposes, and since 2014 also for recreation. The character of changes in intake discharge, water temperature and wellhead pressure observed in 1956-2019, as well as calculations of specific values (the mean, the minimum, the maximum and the standard deviation) have demonstrated considerable diversity and significant variation in these operating parameters. The main cause of changes in these parameters is changing intake operation conditions. Currently, thermal waters are being extracted chiefly from the deepened borehole $\mathrm{C}-1$. Increased extraction from this intake has resulted in decreases in the temperature of thermal water from springs and borehole C-2 and a decline in their discharge or even the disappearance of their outflow. The exploitation of borehole $\mathrm{C}-1$ in such conditions has also caused a drop in water pressure at its head (from 0.49 to $0.34 \mathrm{MPa}$ ) accompanied by an increase in water temperature (from 58 to $82{ }^{\circ} \mathrm{C}$ ). The increase in water temperature is indicative of the presence of deep circulation waters in this intake. Based on the results of long-term (1963-2018) physico-chemical analyses of waters from particular intakes and deep boreholes, dominant chemical types have been distinguished: $\mathrm{Na}-\mathrm{HCO}_{3}-\mathrm{SO}_{4}$ and $\mathrm{Na}-\mathrm{SO}_{4}-\mathrm{HCO}_{3}$, containing fluorides and silica. By using chemical geothermometers, deposit temperatures of Cieplice thermal waters have been estimated $\left(111-138^{\circ} \mathrm{C}\right)$. The obtained results were verified by analysing the degree of saturation of these waters with selected rock-forming minerals by means of GeoT application. The deposit temperature estimated by modelling is c. $123{ }^{\circ} \mathrm{C}$.
\end{abstract}

Keywords Thermal water $\cdot$ Therapeutic water $\cdot$ Spring discharge $\cdot$ Chemical geothermometers $\cdot$ Sudetes Mts

This article is a part of the Topical Collection in Environmental Earth Sciences on "Mineral and Thermal Waters" guest edited by Drs. Adam Porowski, Nina Rman and Istvan Forizs, with James LaMoreaux as the Editor-in-Chief

Elżbieta Liber-Makowska

elzbieta.liber-makowska@pwr.edu.pl

1 Faculty of Geoengineering, Mining and Geology, Wroclaw University of Science and Technology, 27 Wybrzeże Wyspiańskiego St., 50-370 Wrocław, Poland

\section{Introduction}

Thermal therapeutic waters occurring in the Cieplice deposit in the area of Jelenia Góra have been known and used since the thirteenth century, when waters from two springs, currently known as Basenowe Damskie and Basenowe Męskie, were used.

The local spa developed at the turn of the nineteenth century. As a result of prospection works, new springs, later named Marysieńka, Antoni-Wacław, Nowe and Sobieski, were discovered and encased.

With the aim of expanding the knowledge of the geothermal system of Jelenia Góra and increasing the admissible volume of waters extracted from the Cieplice deposit, 
drilling works and hydrogeological research were carried out in the latter part of the twentieth century. They resulted in the execution of two deep boreholes: Cieplice-1 (C-1) and Cieplice-2 (C-2). These holes provided access to thermal waters with temperatures higher than those in the previously existing springs.

All the intakes, both springs and the boreholes, capture slightly mineralized thermal waters. The Cieplice waters have been recognized, in accordance with Polish Geological and Mining Law, as therapeutic waters due to a high concentration of the fluoride ion (above the threshold content of $2 \mathrm{mg} / \mathrm{L}$ ) and an increased meta-silicic acid content (above the threshold content of $70 \mathrm{mg} / \mathrm{L}$ ).

\section{Characteristics of geothermal system}

The reservoir of thermal therapeutic waters in Cieplice is situated in the Sudetes (SW Poland), within the granite Karkonosze massif being a part of a larger tectonic unit- the Karkonosze-Izera crystalline massif.

The area of Cieplice, now a district of the city of Jelenia Góra, is built of Upper-Carboniferous Karkonosze granite underlying Quaternary sediments filling erosional hollows in the bedrock.

The thickness of these Quaternary sediments varies from 5 to $30 \mathrm{~m}$. These are gravels and granite waste, as well as clays, boulder clays, and sandy and gravel sediments covering the floodplains of the rivers Bóbr, Wrzosówka and Kamienna.

Upper-Carboniferous granite is the main water-bearing rock for Cieplice therapeutic waters. It is a Variscan intrusion comprising the main ridge of the Karkonosze, the Jelenia Góra basin, and the western slopes of the Rudawy Janowickie range (Fig. 1). According to more detailed analyses (Borkowska 1966; Mierzejewski 2005; Szałamacha 1964), the Karkonosze granite is coarse-grained and porphyrytic biotitic monzogranite. Granites contain veins of intrusive rocks, chiefly aplites, pegmatites, microgranites or lamprophyres (Fistek and Dowgiałło 2003). The age of granite is estimated at c. 330 to c. 310 million years (Duthou et al. 1991; Marheine et al. 2002).

The occurrence of Cieplice therapeutic waters is heavily dependent on the tectonics of this area. It is expressed chiefly in the form of deep syngenetic fractures: transverse, with a NE-SW strike and the dip angle of $60^{\circ}-90^{\circ}$; longitudinal, with a NW-SE strike and the dip angle of c. $80^{\circ}$, and horizontal, with a small dip angle.

The main dislocation zones of the granitic Karkonosze massif are the intra-Sudetic fault, separating the Karkonosze massif from the Kaczawa metamorphic complex, and the marginal fault of the Karkonosze, separating this massif from the Jelenia Góra basin. In the west, the massif is separated from the gneisses of the Izera Mts by the Rozdroże Izerskie dislocation. The paths of thermal water circulation are related to tectonic zones in the area of Cieplice, a district of Jelenia Góra (Liber-Makowska and Ciężkowski 2018).

The Jelenia Góra basin, containing Cieplice, is a hydrogeological depression formed within Palaeozoic crystalline deposits, only to a small extent filled with Quaternary sedimentary rock mantle.

Waters related to these Quaternary deposits occur within the Holocene alluvia of the Kamienna and Wrzosówka rivers and in Pleistocene sands and gravels (Fistek and Dowgiałło 2003; Marszałek 2010).

Groundwaters found in the Upper Carboniferous granite comprise pore-fissure waters occurring in the upper parts of crystalline deposits and fissure waters related to zones of deep tectonic fractures.

The occurrence of shallower pore-fissure waters is linked to the zone of weathering fissures reaching the depths of 20-30 m, covered with a mantle of waste rock deposits (Marszałek 2010).

In the area of Cieplice, fissure thermal waters of deep circulation occur. The circulation paths of these waters within the granite massif are related to tectonic zones, which form a dense network in the area of Cieplice. An important hydrological role is played by faults with ENE-WSW and NE-SW strikes, corresponding to the valleys of the Kamienna and Wrzosówka rivers. Natural outflows of thermal waters are directly connected with a NE-SW spring fault, meeting the Kamienna fault in the NE, and the Spa Park northern fault in the SW. Both of these dislocations, together with the Spa Park southern fault and the largest Wrzosówka fault zone, make up the hydrogeological structure of Cieplice (Fistek and Dowgiałło 2003).

An important role for deep circulation of thermal waters is also played by the Karkonosze marginal fault, whose NErunning branch crosses Cieplice (Ciężkowski and Mroczkowska 1985; Dowgiałło et al. 1989; Dowgiałło and Fistek 1998; Mierzejewski 2005).

The therapeutic waters occurring here are fissure waters of deep circulation, flowing out to the surface as a result of increased hydrostatic pressure. These waters, of infiltration origin, penetrate the earth's crust and then, circulating within various fissures, migrate towards the earth's surface, getting mineralized and increasing its temperature on the way. The geological structure found in this area has been given the name of the geothermal system of Jelenia Gora.

The therapeutic waters of Cieplice are captured from six springs and two boreholes.

The springs are named: Marysieńka, Sobieski, AntoniWacław, Nowe, Basenowe Damskie and Basenowe Męskie. These shallow intakes have complex balneotechnological structures dating from 1924 to 1930 . These are mostly bell 


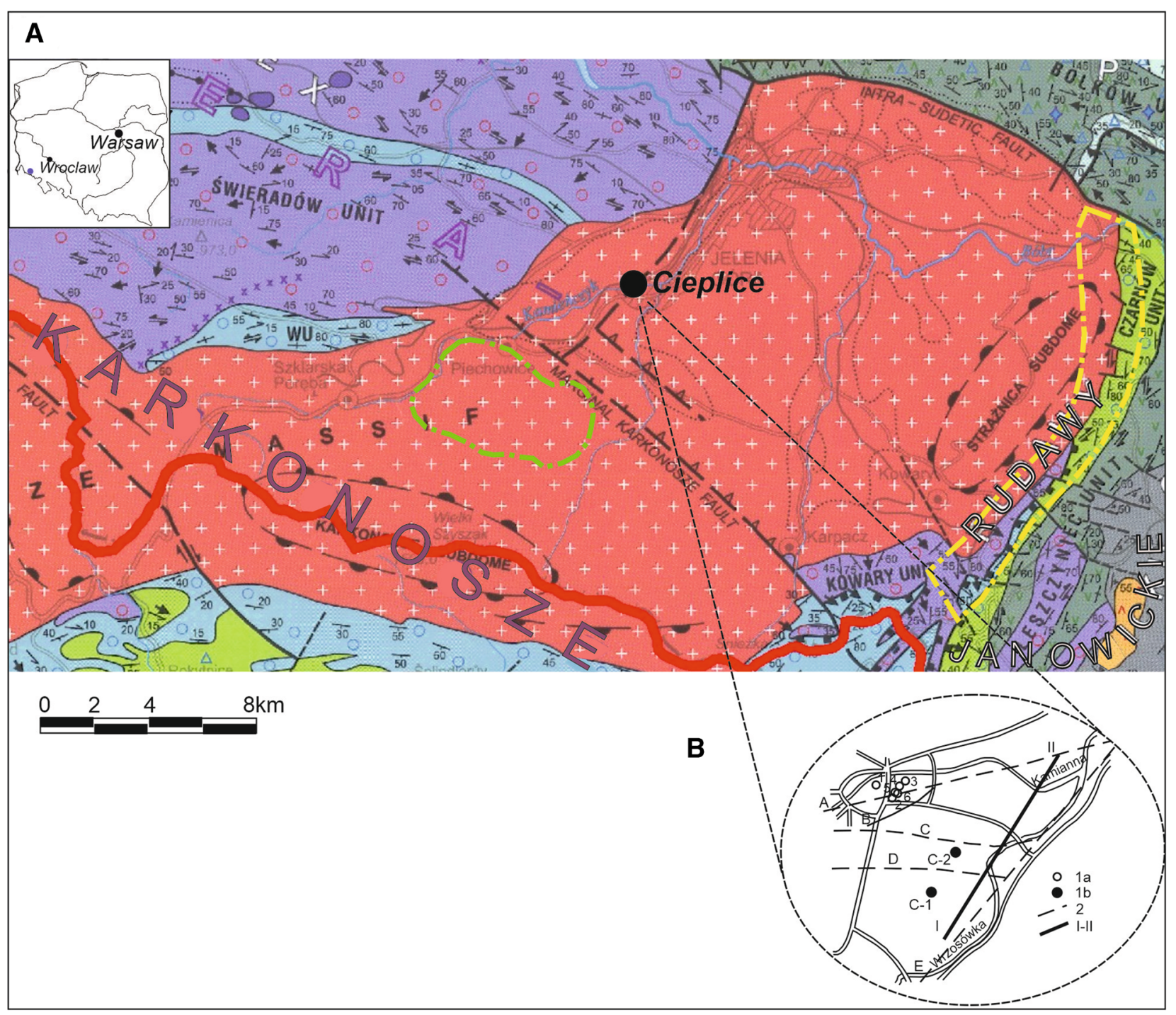

Fig. 1 a Recharge areas of the meteoric component of thermal waters against the background of the geological map of Cieplice region; 1. b Location of thermal water intakes: 1a-springs: 1-Marysieńka, 2-Sobieski, 3-Antoni-Wacław, 4-Nowe, 5-Basenowe Męskie, 6-Basenowe Damskie, 1b-thermal water production boreholes: C-1, C-2;

intakes (4-4.9 m deep) and two wells deepened with shallow boreholes (37.5-48.4 m deep).

There are two deep intakes in boreholes: C-1 $(661 \mathrm{~m}$ deep) and C-2 (750 m deep), drilled in 1970-1971. The C-1 hole was deepened in 1997-1998 to the depth of $2002.5 \mathrm{~m}$ (Fig. 2).

The therapeutic waters of Cieplice are slightly mineralized thermal fluoride waters. The TDS of these waters oscillates from c. 490 to $1000 \mathrm{mg} / \mathrm{L}$. The temperatures of waters from particular intakes vary from $14{ }^{\circ} \mathrm{C}$ for Marysieńka intake to $87^{\circ} \mathrm{C}$ for borehole $\mathrm{C}-1$.

The water temperature is connected with an increased value of geothermal gradient, estimated at 2-faults defined on the basis of geological data: A-Kamienna fault, B-thermal springs fault, C-the north fault of Spa Park, D-the south fault of Spa Park, E-Wrzosówka fault; I-II-geologic cross-section; 1. c Caption (based on: Ciężkowski et al. 1996; Fistek and Dowgiałło 2003; Kiełczawa and Liber-Makowska 2018)

$2.76 \div 3{ }^{\circ} \mathrm{C} / 100 \mathrm{~m}$. However, the actual value is higher, as the gradient was determined during drilling works accompanied by an inflow of cooler waters (Dowgiałło and Fistek 1998).

The infiltration origin of these thermal therapeutic waters has been identified by analysing the results of research into stable isotopes of oxygen and hydrogen in molecules of these waters (Dowgiallo 1973; Ciężkowski et al. 1992, 1996). The values of $\delta^{18} \mathrm{O}$ and $\delta^{2} \mathrm{H}$ for waters from particular intakes in Cieplice range from -10.2 to $-10.55 \%$ and from -71 to $-74 \%$, respectively. Slightly different values of light isotopes of oxygen and hydrogen 


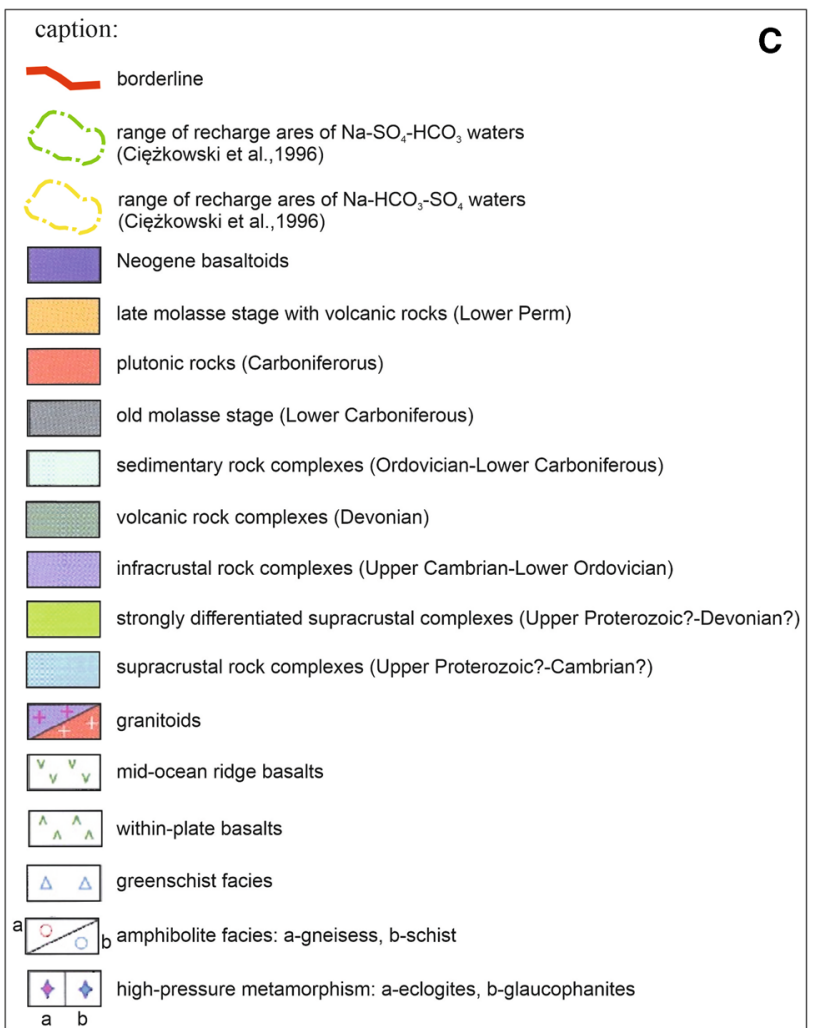

Fig. 1 (continued)

are characteristic of waters from Sobieski intake $(-9.7 \div$ $-9.85 \%$ and $-68 \div-69.7 \%$ respectively).

According to Ciężkowski et al. (1996), Antoni-Wacław and Marysieńka intakes contain mixed waters with varying proportions of slightly mineralized waters of modern infiltration. In Sobieski intake, modern infiltration waters are extracted, while the other intakes have glacial waters. The extent of probable recharge areas of the infiltration component against the backdrop of geological makeup is shown in Fig. 1.

\section{Methods and experimental data}

The character of changes in operating parameters such as spring discharge, wellhead pressure and water temperature at the outflow has been determined on the basis of measurements conducted in 1956-2019 as a part of monitoring activities of the Mining Division of the Cieplice Health Resort Ltd., a part of the Polish Health Resort Group affiliated with the KGHM Polska Miedź S.A corporate group.

Measurements of spring discharge are performed by using a volumetric method, i.e. measuring the volume of flow in a unit of time. As most Cieplice springs are currently out of use, discharge and water temperature measurements are

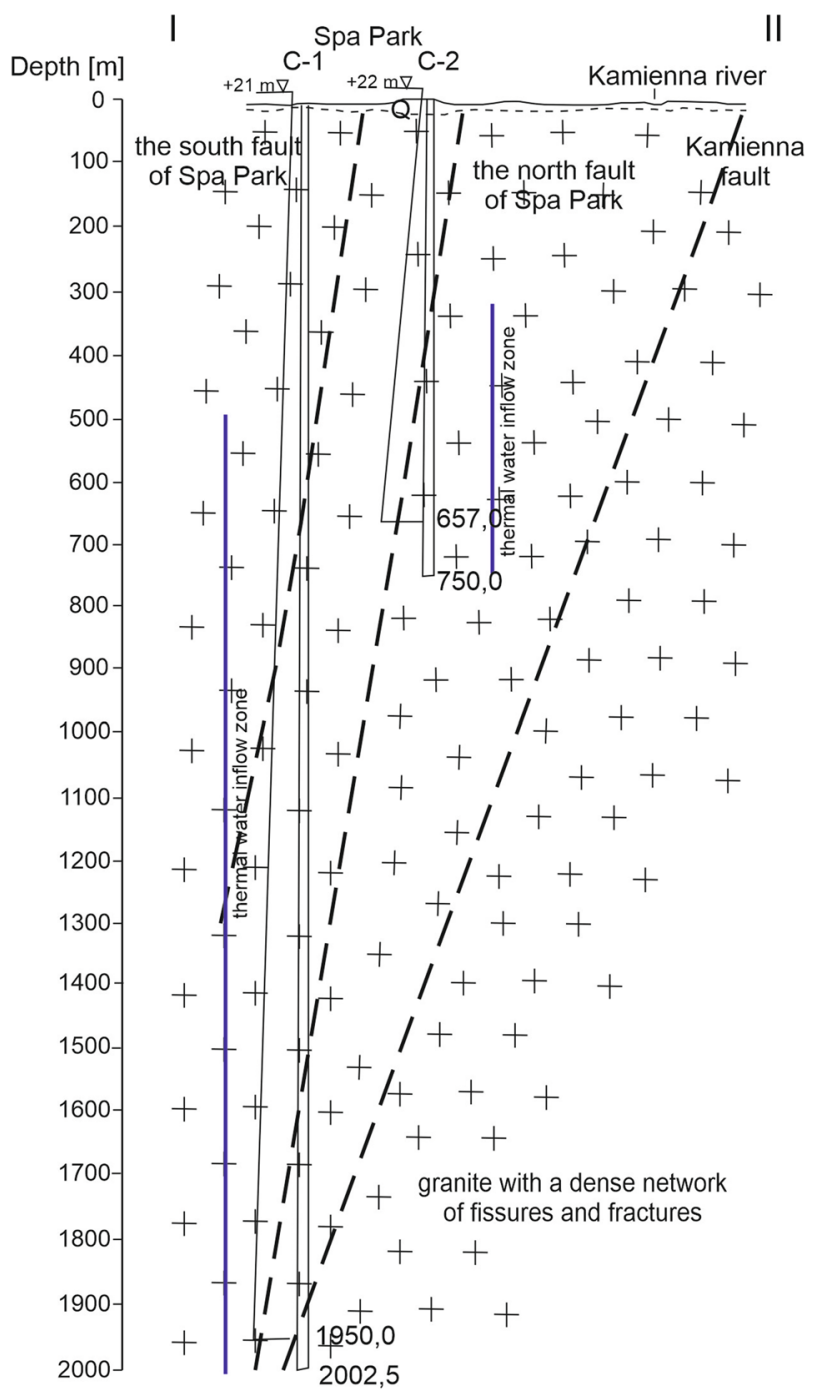

Fig. 2 Simplified geologic cross-section through C-1 and C-2 boreholes (based on Fistek and Dowgiałło 2003)

conducted once a month for Basenowe Męskie and Sobieski springs. Water temperature is measured weekly in Nowe and Marysieńka intakes. Such observations are not conducted in Basenowe Damskie (since 2001) and Sobieski (since 1974) intakes. In boreholes C-1 and C-2, pressure and water temperature measurements are performed once a week by reading the electronic manometer and thermometer placed on the wellheads.

The data used in these investigations were verified. Additionally, check measurements of basic operation parameters were performed for Basenowe Męskie spring and boreholes C-1 and C-2.

Investigations of changes in chemical parameters of these waters were based on the results of physico-chemical analyses conducted in 1963-2018. Over these years, water analyses were performed in several laboratories (e.g. in the 
Spa Industry Project and Service Bureau "Balneoprojekt", the Central Mining Institute), so the used data were verified before the study was launched.

Unfortunately, it is not possible to specify the methods of analyses which have been used in "Balneoprojekt" Laboratory because the Bureau does not exists nowadays. The Central Mining Institute laboratory was authorised by PCA (Polish Centre of Accreditation) in 1997 and performs analyses using accredited techniques and procedures.

The collected data were used to perform an overall analysis of water mineralization degree, relative proportions of major ions, the presence of pharmacodynamic components and water temperatures at the outflows.

The data from the last 63 years were verified by analysing the history of the methodology employed for measuring particular reservoir parameters with the aim of excluding possible recurrent errors related to the specific method of performing measurements such as: changing measurement instruments (manometers and thermometers), changing conditions of performing measurements (e.g. changing the height of water overflow from intake) or changes in the staff performing these measurements.

Measurements conducted in comparable conditions and with comparable accuracy were taken into account. Statistical methods were employed to identify the outliers whose rejection must be properly justified. It was assumed that for parameter values following a normal distribution, the outlier deviates from the mean value plus three standard deviations.

In some cases, extreme changes in the studied parameters were related to changes in extraction conditions (Fig. 3), and measurement results may satisfy the condition of normal distribution only for periods characterized by stable extraction conditions.

The presented modelling of selected hydrodynamic and hydrochemical parameters of the Cieplice thermal healing water reservoir consisted mainly in determining the nature of variability and estimating possible changes in these parameters.

\section{Results and discussion}

\section{Characteristics of operation parameters variation}

All thermal therapeutic water intakes in Cieplice, both springs and boreholes, are artesian flows. The thermal waters extracted from the main borehole $\mathrm{C}-1$ are used for balneotherapeutic and recreational purposes. Additionally, waters from springs Nowe and Marysieńka are used chiefly for industrial purposes. Owing to small discharge and fluctuations in water temperature and quantitative and qualitative parameters, waters from the other springs are

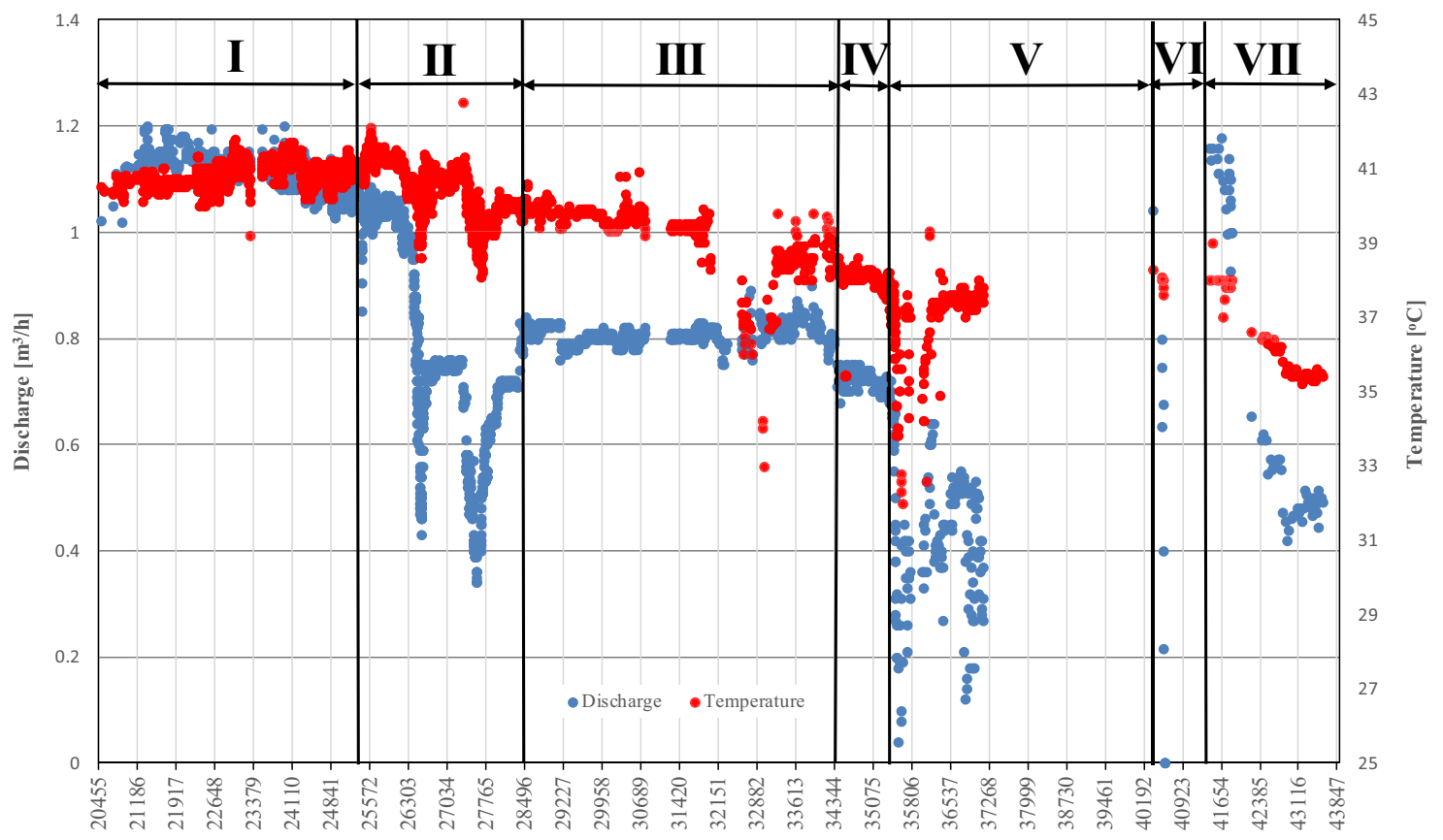

Fig. 3 Changes in water temperature and the discharge of Basenowe Męskie intake in Cieplice-Jelenia Góra in selected exploitation periods (following Liber 2008, Kiełczawa and Liber-Makowska 2018modified and updated): I start of exploitation (stabilization), II drill- ing and examination of $\mathrm{C}-1$ and $\mathrm{C}-2$ boreholes, III stabilization, IV increased extraction from borehole $\mathrm{C}-2, \mathrm{~V}$ deepening and examination of borehole $\mathrm{C}-1$, VI exploration during borehole reconstruction C-1, VII exploitation of borehole C-1 
not used. Also, borehole C-2 is not operated, which is due to the disappearance of artesian flow in this intake caused by the exploitation of C-1 borehole launched in 2012 .

To characterize changes in spring discharge, water temperature and wellhead pressure, long-term average, the minimum and the maximum values, and the standard deviation were determined. The calculation results for basic values characterizing the range of changes in operation parameters in 1956-2019 are shown in Table 1.

The observed character of changes in intake discharge, water temperature and wellhead pressure, as well as the conducted calculations, demonstrate considerable diversity and changeability throughout the study period. The reasons for such considerable changes in these operation parameters should be linked with changing conditions of their exploitation. This method of estimating changes in reservoir parameters was used for the first time in the work of the authors (Liber 2008; Kiełczawa and LiberMakowska 2018).

The character of changes in recharge and water temperature in 1956-2019, exemplified by Basenowe Męskie intake, is indicated in Fig. 3. The distinguished operation periods with extreme changes in the discharge of this intake are similar for the remaining intakes.

Large fluctuations in water temperature and spring discharge throughout the operation period due to anthropogenic factors make it impossible to determine the size of the influence of natural factors, which is usually smaller. Assessing the influence of natural factors is only possible for periods characterized by stable exploitation conditions.

A considerable drop in water temperature and spring discharge (Table 1) or even disappearance of their outflows has been caused by drilling and hydrogeological works connected with the execution of C-1 and C-2 boreholes (in 1970-1971), the deepening of borehole C-1 (in 1997-1998) and the reconstruction of $\mathrm{C}-1$ borehole and preparing it for extraction (in 2011-2012). A smaller decrease in water temperature and spring discharge has been connected with the operation of boreholes C-1 (since 2012) or C-2 (since 1973) and increased extraction of waters from these intakes (since 2014 and 1994 respectively).

After the 2011-2012 reconstruction of the deepened borehole C-1, the Cieplice Health Resort started the exploitation of this borehole while discontiunuing extraction from C-2 borehole. Prior to the reconstruction, the Resort extracted about $50,000-55,000 \mathrm{~m}^{3}$ of thermal therapeutic water per year from borehole C-2, and about $3400 \mathrm{~m}^{3}$ per year from Marysieńka and Nowe springs. The thermal waters extracted currently from borehole $\mathrm{C}-1$ are used for balneotherapeutic purposes, and since 2014-also for recreational purposes in the pools of the Termy Cieplickie facility. The Health Resort and the Termy Cieplickie are supplied with $150,000-200,000 \mathrm{~m}^{3}$ of water extracted yearly from borehole $\mathrm{C}-1$, and about $5000 \mathrm{~m}^{3}$ extracted from shallow springs Marysieńka and Nowe (Kiełczawa and Liber-Makowska 2018).

Table 1 Values characterizing changes in operation parameters of therapeutic water intakes in Cieplice

\begin{tabular}{|c|c|c|c|c|c|c|}
\hline Intake & Period & $\begin{array}{l}\text { Number of measure- } \\
\text { ments }\end{array}$ & Mean & Minimum (date) & Maximum (date) & $\begin{array}{l}\text { Standard } \\
\text { deviation }\end{array}$ \\
\hline \multicolumn{7}{|c|}{ Water temperature $\left({ }^{\circ} \mathrm{C}\right)$} \\
\hline Marysieńka & 1958-2019 & 2901 & 20.9 & $14.2(1997-05-09)$ & $27.4(1959-10-29)$ & 1.6 \\
\hline Sobieski & 1956-2019 & 2839 & 22.1 & $17.6(1961-06-29)$ & $29.0(1965-04-29)$ & 1.3 \\
\hline Antoni-Wacław & 1956-1999 & 4413 & 19.5 & 13.4 (1998-12-03) & $29.9(1958-06-06)$ & 1.9 \\
\hline Nowe & 1956-2019 & 3120 & 32.1 & $20.0(2012-08-23)$ & $40.6(1957-05-16)$ & 3.4 \\
\hline Basenowe Damskie & 1956-2001 & 3853 & 41.5 & 23.5 (1997-10-09) & $48.1(1973-09-13)$ & 2.1 \\
\hline Basenowe Męskie & 1956-2019 & 4352 & 40.3 & $32.0(1997-07-25)$ & $42.8(1974-10-31)$ & 1.2 \\
\hline $\mathrm{C}-1$ & 2012-2019 & 473 & 76.1 & $58.0(2012-07-15)$ & $82.0(2018-02-14)$ & 5.80 \\
\hline $\mathrm{C}-2$ & $1973-2018$ & 1861 & 54.2 & $12.0(2018-02-28)$ & $68.5(1993-04-22)$ & 12.9 \\
\hline \multicolumn{7}{|l|}{ Discharge $\left(m^{3} / h\right)$} \\
\hline Marysieńka & $1961-1994$ & 11 & 2.82 & - & - & - \\
\hline Sobieski & 1956-2019 & 2451 & 0.05 & $0.00(1961-06-29)$ & $0.21(1965-04-29)$ & 0.05 \\
\hline Antoni-Wacław & $1962-1974$ & 182 & 3.81 & 0.14 & 6.06 & 1.17 \\
\hline Nowe & 1975 & 1 & 4.0 & - & - & - \\
\hline Basenowe Damskie & $1956-2001$ & 3874 & 1.37 & 0.06 (1997-06-19) & $1.92(1958-07-05)$ & 0.47 \\
\hline Basenowe Meskie & 1956-2019 & 4398 & 0.94 & $0.0(2011-02-28)$ & $1.70(1961-10-21)$ & 0.23 \\
\hline \multicolumn{7}{|c|}{ Wellhead pressure $(\mathrm{MPa})$} \\
\hline $\mathrm{C}-1$ & 2012-2019 & 473 & 0.41 & $0.34(2017-12-20)$ & 0.49 (2014-02-19) & 0.04 \\
\hline $\mathrm{C}-2$ & $1973-2018$ & 1898 & 0.18 & $0.0(1998-03-02)$ & $1.42(1998-06-18)$ & 0.11 \\
\hline
\end{tabular}


The exploitation of $\mathrm{C}-1$ borehole causes pressure drops at the head of C-2 borehole or even the disappearance of artesian flow, with the simultaneous considerable drop in water temperature from 68.5 to $12{ }^{\circ} \mathrm{C}$. Exploitation with this level of extraction also leads to decreases in water temperature and spring discharge (Table 1 and Fig. 3).

Increased extraction of water from borehole $\mathrm{C}-1$ connected with the opening of the Termy Cieplickie facility (in 2014) has led to wellhead pressure drop from 0.49 to $0.34 \mathrm{MPa}$, accompanied by an increase in water temperature from 58 to $82{ }^{\circ} \mathrm{C}$ (Table 1 and Fig. 4). The observed increase in water temperature may be indicative of the outflow of deep circulation waters from this intake.

The described dynamic changes in operation parameters throughout the last 60 years are connected with changing operating conditions caused by deep drilling and hydrogeological tests conducted in boreholes $\mathrm{C}-1$ and $\mathrm{C}-2$. However, these are springs which are particularly vulnerable to such operating conditions, which is manifested by decreasing water temperature and intake discharge or even disappearance of artesian flow. The conducted research has confirmed earlier assessments of hydrogeological conditions in the Cieplice reservoir related to hydraulic connections between deep boreholes and springs (Liber 2008).

\section{Estimation of reservoir temperature}

The studied waters represent two main hydrochemical types, i.e. $\mathrm{Na}-\mathrm{HCO}_{3}-\mathrm{SO}_{4}$ and $\mathrm{Na}-\mathrm{SO}_{4}-\mathrm{HCO}_{3}$ (Table 2, Fig. 5). Within these types, two periodically occurring secondary types with $\mathrm{Cl}^{-}$and $\mathrm{Ca}^{2+}$ ions can be also distinguished (Table 2). Pharmacodynamic components include considerable amounts of fluoride ions $(2-13.5 \mathrm{mg} / \mathrm{L})$ and metasilicic acid (a maximum of $141 \mathrm{mg} / \mathrm{L}$ ). The discussed waters are characterized by low TDS oscillating between $490 \mathrm{mg} / \mathrm{L}$ (Antoni-Wacław) and $1000 \mathrm{mg} / \mathrm{L}$ (Sobieski) and the $\mathrm{pH}$ in the range of 6.4-9.4.

The temperatures of waters from particular intakes range from $14{ }^{\circ} \mathrm{C}$ in $\mathrm{M}$ (Marysieńka) intake to $87{ }^{\circ} \mathrm{C}$ in borehole $\mathrm{C}-1$. The highest water temperatures in shallow intakes, reaching $43^{\circ} \mathrm{C}$ and $45^{\circ} \mathrm{C}$, were measured in $\mathrm{BM}$ (Basenowe Męskie) and BD (Basenowe Damskie) springs respectively. The waters can be divided into two groups, i.e. waters with $\mathrm{T} \leq 27^{\circ} \mathrm{C}$ (intakes Antoni-Wacław, Marysieńka and Sobieski) and waters with $\mathrm{T} \geq 27{ }^{\circ} \mathrm{C}$ (the remaining intakes). This fact is reflected in TDS changes depending on water temperature at the outflow (Fig. 6). The waters in C-1, C-2, BD and BM intakes are characterized by TDS fluctuations up to c. $100 \mathrm{mg} / \mathrm{L}$. The TDS in waters from the first group of intakes undergo larger changes, which is probably due to a more intensive inflow of slightly mineralised and cooler waters. The max temperature of Sobieski spring is

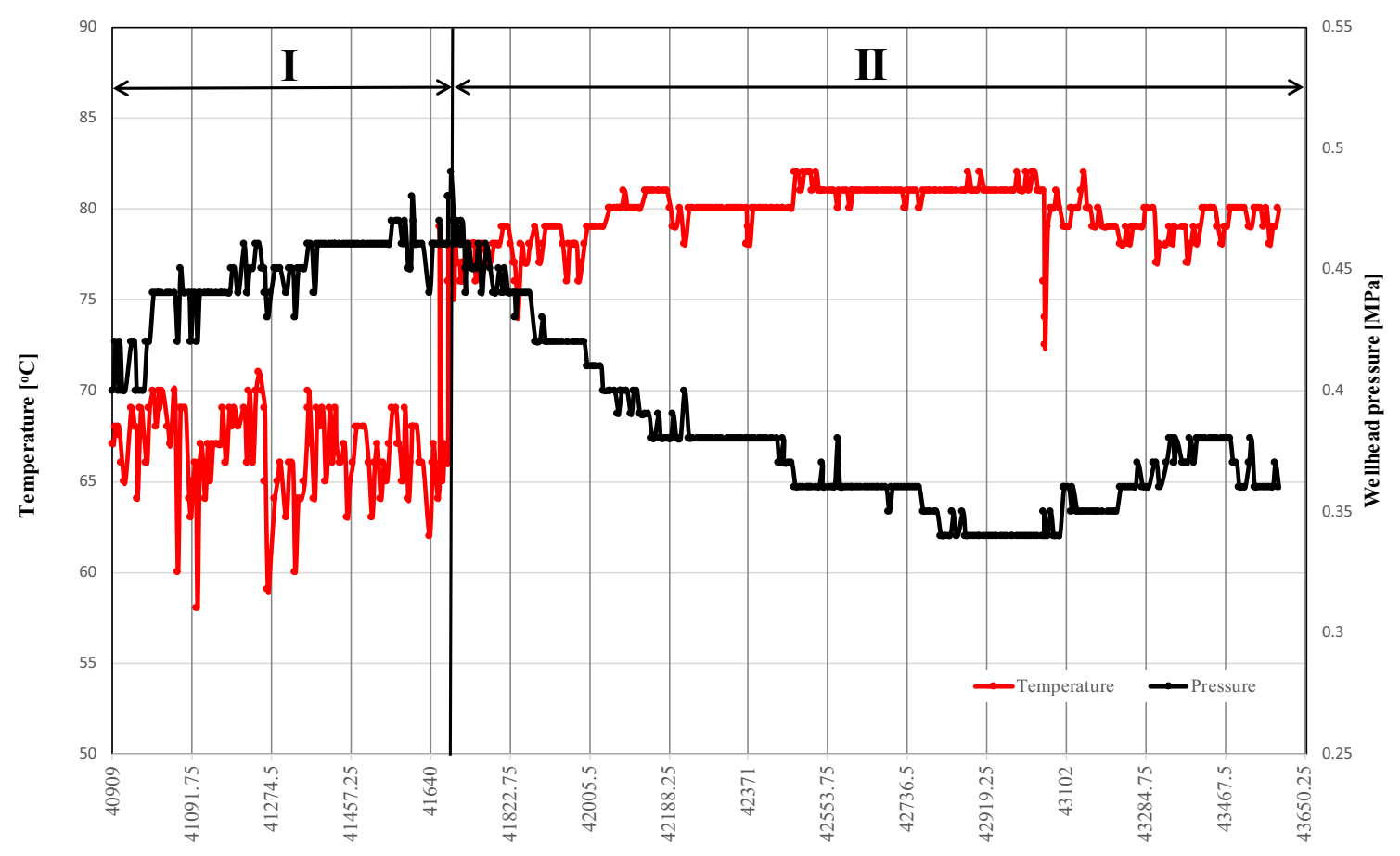

Fig. 4 Changes in water temperature and wellhead pressure in C-1 borehole over selected operation periods: I start of exploitation, II increased extraction 
Table 2 Minimum and maximum contents of major ions and specific components expressed by Kurlov formula (based on data 1963-2018; $\mathrm{H}_{2} \mathrm{SiO}_{3}$ - periodically affect the chemical type of water; specific components according to Act of 9 June 2011, Polish Geological and Mining Law)

\begin{tabular}{ll}
\hline Intake & Kurlov formula \\
\hline $\mathrm{C}-1$ & $\mathrm{~F}^{10-12} \mathrm{H}_{2} \mathrm{SiO}_{3}^{125-141} \mathrm{M}^{0.5-0.66} \frac{\mathrm{SO}_{4}^{43-46} \mathrm{HCO}_{3}^{29-32}}{\mathrm{Na}^{87-93}} \mathrm{~T}^{65-87}$ \\
$\mathrm{C}-2$ & $\mathrm{~F}^{10-13.5} \mathrm{H}_{2} \mathrm{SiO}_{3}^{72-136} \mathrm{M}^{0.59-0.66} \frac{\mathrm{SO}_{4}^{39-46} \mathrm{HCO}_{3}^{25-33}}{\mathrm{Na}^{88-92}} \mathrm{~T}^{26-65}$ \\
Basenowe Damskie (BD) & $\mathrm{F}^{10-13} \mathrm{H}_{2} \mathrm{SiO}_{3}^{72-136} \mathrm{M}^{0.58-0.68} \frac{\mathrm{SO}_{4}^{39-46} \mathrm{HCO}_{3}^{26-35}}{\mathrm{Na}^{89-92}} \mathrm{~T}^{36-45}$ \\
Basenowe Męskie (BM) & $\mathrm{F}^{10-13.5} \mathrm{H}_{2} \mathrm{SiO}_{3}^{65-117} \mathrm{M}^{0.58-0.68} \frac{\mathrm{SO}_{4}^{32-45} \mathrm{HCO}_{3}^{25-37}}{\mathrm{Na}^{85-94}} \mathrm{~T}^{35-43}$ \\
Nowe (N) & $\mathrm{F}^{9-13} \mathrm{H}_{2} \mathrm{SiO}_{3}^{59-114} \mathrm{M}^{0.56-0.7} \frac{\mathrm{SO}_{4}^{37-45} \mathrm{HCO}_{3}^{25-37} \mathrm{Cl}^{15-25}}{\mathrm{Na}^{80-92}} \mathrm{~T}^{26-38}$ \\
Marysieńka (M) & $\mathrm{F}^{7-13} \mathrm{H}_{2} \mathrm{SiO}_{3}^{70-111} \mathrm{M}^{0.56-0.7} \frac{\mathrm{SO}_{4}^{34-45} \mathrm{HCO}_{3}^{26-39} \mathrm{Cl}^{15-28}}{\mathrm{Na}^{80-92}} \mathrm{~T}^{14-24}$ \\
Antoni-Wacław (A-W) & $\mathrm{F}^{4-12}\left(\mathrm{H}_{2} \mathrm{SiO}_{3}\right) \mathrm{M}^{0.49-0.76} \frac{\mathrm{HCO}_{3}^{32-57} \mathrm{SO}_{4}^{2-43} \mathrm{Cl}^{16-25}}{\mathrm{Na}^{57-80} \mathrm{C}^{11-30}} \mathrm{~T}^{16-23}$ \\
Sobieski (S) & $\mathrm{F}^{2-3}\left(\mathrm{H}_{2} \mathrm{SiO}_{3}\right) \mathrm{M}^{0.4-1.0} \frac{\mathrm{HCO}_{3}^{40-56} \mathrm{Cl}^{17-39} \mathrm{SO}_{4}^{17-32}}{\mathrm{Na}^{42-60} \mathrm{Ca}^{21-41}} \mathrm{~T}^{21-27}$ \\
\hline
\end{tabular}

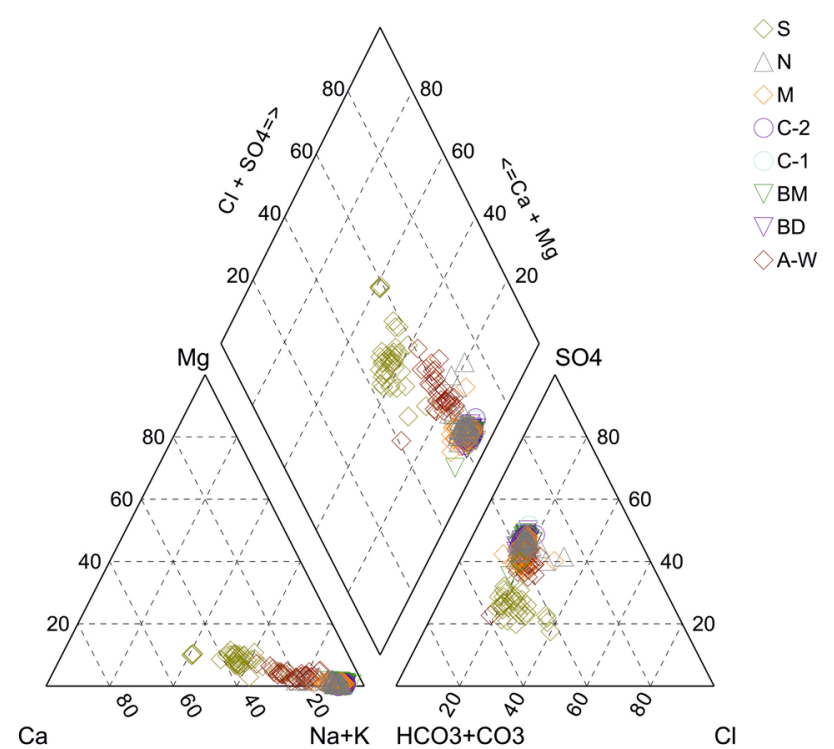

Fig. 5 Chemical composition of thermal waters from Cieplice on the Piper diagram (modeled using AquaChem software)

the border-temperature $\left(27^{\circ} \mathrm{C}\right)$ of the group. The mixing of waters from different systems can be indicated by the varying TDS of waters from Nowe intake (Fig. 6), which chemically correspond to the second group. One should also note considerable similarities between the proportions of the meq of major ions (Table 2). This fact is indicative of particular intakes being recharged by waters from one deep circulation system, as mentioned by Dowgiałło (2000).

The division of the discussed waters into the above groups can be observed when comparing data plotted on a Giggenbach diagram (Fig. 7). Waters from Antoni-Wacław and Sobieski intakes are wholly contained in a field of waters "immature" in terms of their reactions with the rock medium. These are therefore mixed waters with a high proportion of shallow circulation waters or a very short time of reaction with the rock medium, which is indicative of a

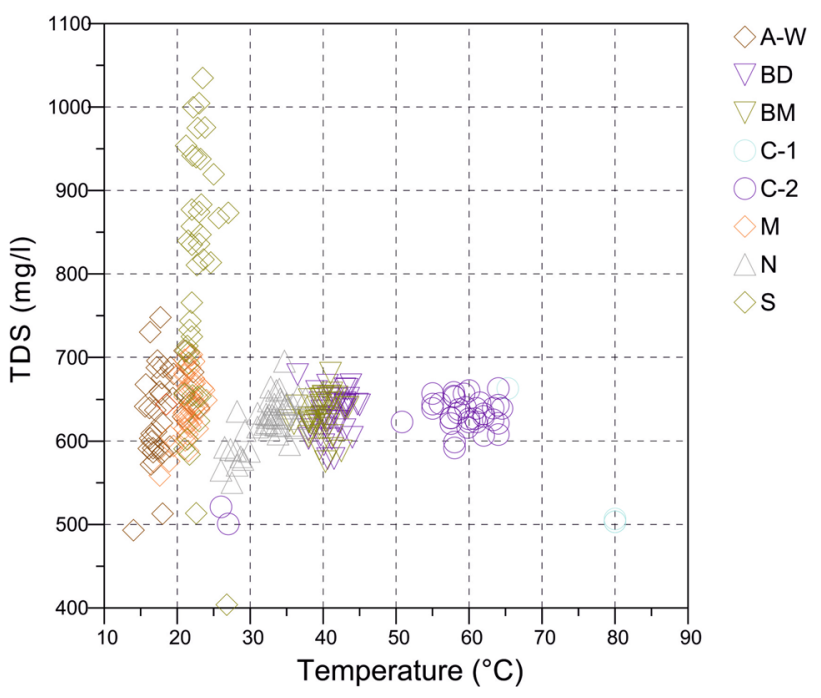

Fig. 6 TDS versus temperature for all sampled waters

short flow time. Waters from Marysieńka and Nowe intakes exhibit the features of waters in between ,immature” and partly „balanced” or mixed waters. Waters from the other intakes (C-1, C-2, BM, and BD) are characterized by an increasing equilibrium with the rock medium and they can be ordered from the least (BD, BM, C-2) to the most balanced (C-1). The Giggenbach diagram makes it possible to simultaneously determine the ,maturity” of waters and estimate their temperatures. It is noteworthy that Dowgiałło (2007) obtained similar results based on a smaller number of analyses.

Based on the ion ratios of major cations, the concentration of silica in the analysed waters and the degree of saturation of thermal waters with rock-forming minerals, repeated attempts at estimating deposit temperatures of the Cieplice system have been made. One should mention works by Leśniak and Nowak (1993), Dowgiałło (2000, 2002), Porowski and Dowgiałło (2009) or Dobrzyński and Leśniak 


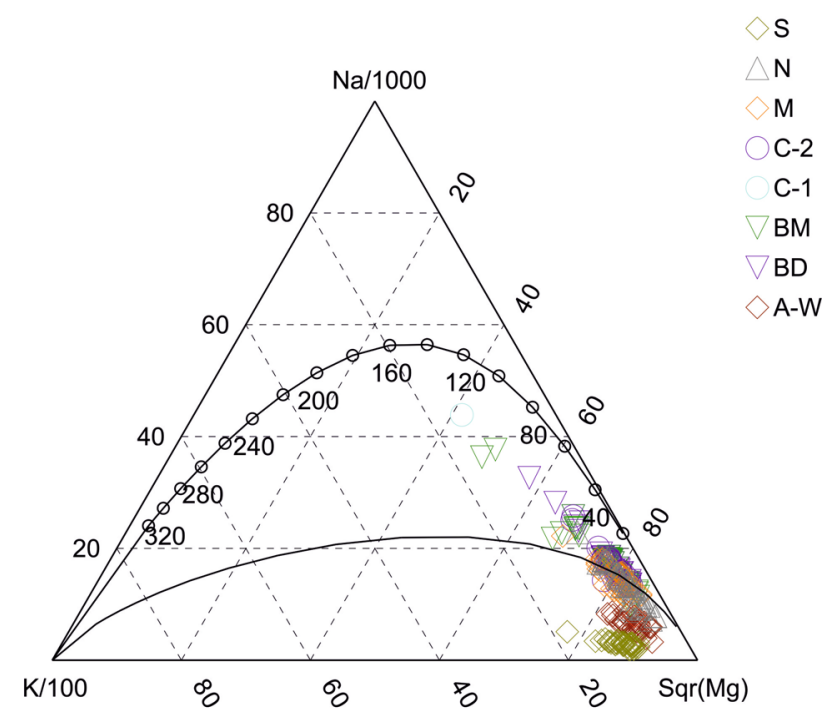

Fig. 7 Valuation of water-rock equilibration temperatures for Cieplice thermal waters (modeled using AquaChem software)

Table 3 Reservoir temperature of Cieplice geothermal system estimated with the use of chemical geothermometers ( $\mathrm{Si}_{\text {(quartz) }}$ (Fournier and Potter 1982); $\mathrm{Si}_{\text {(chalcedon) }}$ (Fournier 1977); Na-K-Ca (Fournier and Truesdell, 1973), K-Mg (Giggenbach 1988), Na-K (Arnórsson 2000)

\begin{tabular}{|c|c|c|c|c|}
\hline & C-1 & C-2 & Nowe & Author \\
\hline $\mathrm{Si}_{\text {(quartz) }}$ & $\begin{array}{l}138 \\
94.4 \\
94\end{array}$ & $\begin{array}{l}128 \\
132\end{array}$ & $\begin{array}{l}119 \\
118\end{array}$ & $\begin{array}{l}\text { Current research } \\
\text { Porowski and Dowgiałło (2009) } \\
\text { Dowgiałło et al. (2005) }\end{array}$ \\
\hline $\mathrm{Si}_{\text {(chalcedon) }}$ & $\begin{array}{l}111 \\
66 \\
63.9\end{array}$ & $\begin{array}{l}100 \\
94 \\
105\end{array}$ & $\begin{array}{l}90 \\
89.7\end{array}$ & $\begin{array}{l}\text { Current research } \\
\text { Dowgiałło (2002) } \\
\text { Porowski and Dowgiałło (2009) }\end{array}$ \\
\hline $\mathrm{Na}-\mathrm{K}-\mathrm{Ca}$ & $\begin{array}{l}139 \\
99.9 \\
127\end{array}$ & $\begin{array}{l}97 \\
94 \\
116\end{array}$ & $\begin{array}{l}88 \\
95.9\end{array}$ & $\begin{array}{l}\text { Current research } \\
\text { Dowgiałło (2002) } \\
\text { Porowski and Dowgiałło (2009) }\end{array}$ \\
\hline $\mathrm{Na}-\mathrm{K}$ & $\begin{array}{l}117 \\
98.2 \\
99\end{array}$ & $\begin{array}{l}114 \\
98.1 \\
91\end{array}$ & $\begin{array}{l}148 \\
113.6\end{array}$ & $\begin{array}{l}\text { Current research } \\
\text { Porowski and Dowgiałło (2009) } \\
\text { Dowgiałło et al. (2005) }\end{array}$ \\
\hline $\mathrm{K}-\mathrm{Mg}$ & 80 & 78 & 82 & Current research \\
\hline
\end{tabular}

Geothermometers: $\mathrm{Si}_{\text {(quartz) }}$ (Fournier and Potter 1982); $\mathrm{Si}_{\text {(chalcedon) }}$ (Fournier 1977; Na-K-Ca (Fournier and Truesdell 1973), K-Mg (Giggenbach 1988), Na-K (Arnórsson 2000)

(2010). The results of temperature estimation with the use of chemical geothermometers are shown in Table 3. Despite slight fluctuations in the proportions of particular ions and silica in the composition of the discussed waters, there is a noticeable variation in the obtained results of temperature estimation (Table 3).

One could expect, however, those probable temperatures of deep circulation waters (intake C-1) determined by means of a silica geothermometer will fall in the range from c. 111 to c. $138{ }^{\circ} \mathrm{C}$. It is noteworthy that during the deepening of C-1 intake, water temperature of $97.7^{\circ} \mathrm{C}$ was measured near its bottom (Dowgiałło 2000, 2002). However, these values are different from those obtained by using cation (Na-K or Na-K-Ca) geothermometers (Table 3). It should be observed that the application of cation geothermometers requires a few basic assumptions, the most important of them being that thermal waters and minerals in the waterbearing medium are in a thermodynamic equilibrium or close to this state.

Moreover, this equilibrium should be maintained along the whole path of thermal water movement to the intake or artesian flow zone (Neupane et al. 2017).

When it comes to cation equilibriums, only waters from intakes $\mathrm{C}-1$ and $\mathrm{C}-2$ exhibit the characteristics of partial equilibrium waters (Fig. 7). In such cases, Dowgiałło (2007) recommends the prudent application of cation geothermometers, as lack of thermodynamic equilibrium of the system results in hardly reliable water temperatures obtained from these empirical equations. According to Kiełczawa and Liber-Makowska (2018), waters from particular intakes (except C-1 intake) are (at standard conditions) oversaturated with microcline, clay minerals, chalcedony and fluorite, and slightly undersaturated with respect to anorthite. This is why the authors regard the results obtained by using a chalcedony geothermometer as more reliable (Table 3). Due to the $\mathrm{pH}$ of the studied waters ranging from 6.5 to 6.8 , the authors adopted silica concentrations reduced to the non-ionized form $\left(\mathrm{H}_{4} \mathrm{SiO}_{4}^{0}\right)$, as in the conditions of $\mathrm{pH}<9$, this form of silica considerably prevails over the ion forms $\left(\mathrm{H}_{3} \mathrm{SiO}_{4}{ }^{-}\right.$and $\left.\mathrm{H}_{2} \mathrm{SiO}_{4}{ }^{2-}\right)$, which can be treated as negligible in this case (Langmuir 1997; Arnórsson 2000).

In the case when concentrations of the main cations are not controlled by the dissolution of feldspars or clay minerals, or when thermal waters to not attain full chemical equilibrium with the minerals of the water-bearing medium, more reliable estimations of deposit temperatures are obtained by analysing the degree of water saturation. The application of this method has been discussed in detail by Reed and Spycher (1984), Pang and Reed (1998), and Spycher et al. (2014).

To determine the deposit temperature of Cieplice waters, an application of GeoT software was used (Spycher et al. 2016). This app makes it possible to take account of the degassing, mixing with cool waters and diluting of the original geothermal solution in the simulation process.

The analysis was based on the results of a 2017 physicochemical analysis of waters provided by the health resort. Deposit temperatures were estimated for waters from $\mathrm{C}-1$ intake. The other intakes were not included in the estimation as, owing to the current water management, the resort relies on extraction from this particular intake. What is more, it is the deepest intake in Cieplice so the authors assumed that the obtained results would reflect deep deposit conditions in 
the best possible way. A wide range of rock-forming minerals was chosen for the simulation, the most important of which are low albite, anorthite, calcite, Ca-beidellite, Mgbeidellite, chalcedony, fluorite, kaolinite, microcline, muscovite, phlogopite, quartz and talc. In view of a very low concentration of $\mathrm{Al}^{3+}$ ions, constant supply of these ions was secured to offset the influence of re-equilibration as a result of water cooling, with the assumption of the solution's equilibrium with kaolinite (Spycher et al. 2016). With these assumptions, water temperatures in the range of $108-136^{\circ} \mathrm{C}$ were obtained, with the lowest SI median value for the whole mineral complex at c. $123^{\circ} \mathrm{C}$.

These values are close to the temperatures $\left(110 \pm 10^{\circ} \mathrm{C}\right)$ obtained by Dobrzyński and Leśniak (2010). The obtained results (Figs. 8, 9) suggest that the system exhibits a better chemical equilibrium in such temperature conditions. Therefore, one can assume the presence of geothermal waters with temperatures of around $120 \pm 10{ }^{\circ} \mathrm{C}$ in the area of Cieplice. What is more, these values are also close to the temperatures obtained with the use of $\mathrm{Si}_{\text {chalcedon }}$ and $\mathrm{Na}-\mathrm{K}$ chemical geothermometers (Table 3), apart from the remaining geothermometers.

\section{Conclusions}

The area of Cieplice is a prospective geothermal area with a possibility of obtaining slightly mineralized fluoride and siliceous geothermal waters with temperatures ranging from 108 to $136^{\circ} \mathrm{C}$, and in all likelihood-reaching $123^{\circ} \mathrm{C}$. The temperatures measured with the use of classic chemical geothermometers, with a correction of non-ionized silica concentrations, fall within the range of $80-139{ }^{\circ} \mathrm{C}$. The most uncertain temperature values were obtained from a Na-K-Ca geothermometer $\left(139^{\circ} \mathrm{C}\right)$. Large similarities between water mineralisation degree and relative proportions of major ions in particular springs and deep boreholes

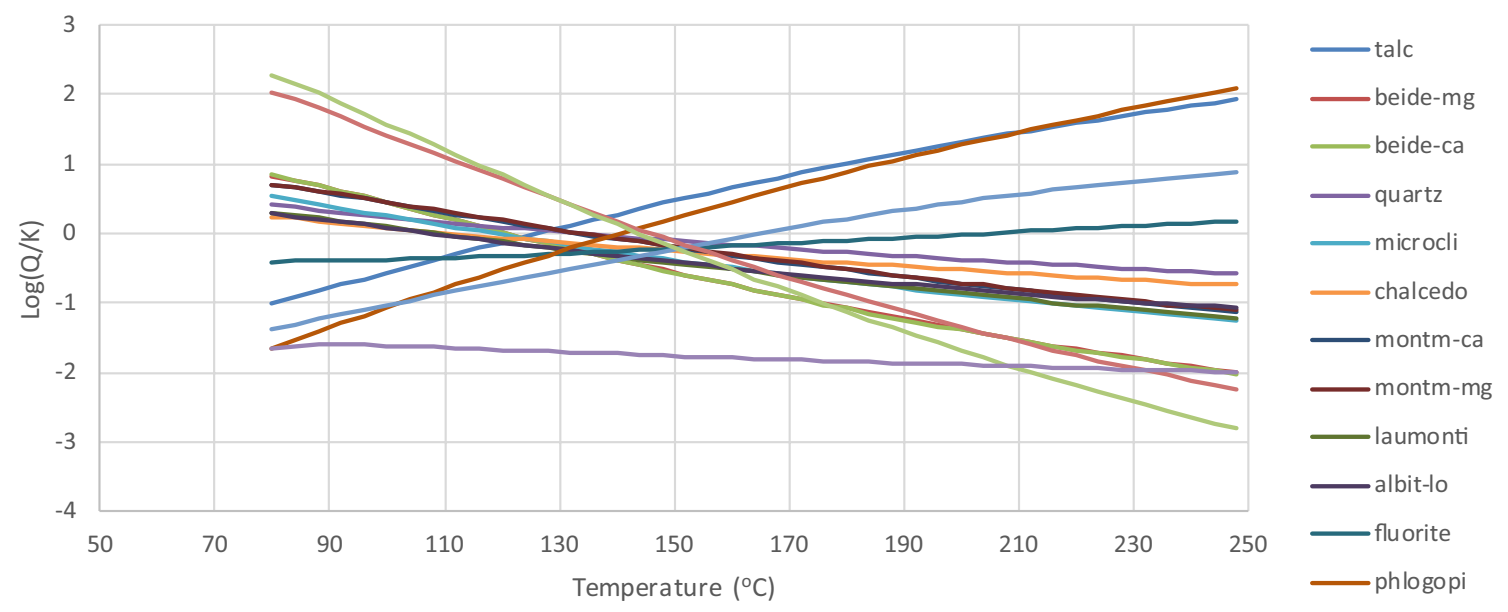

Fig. 8 Computed saturation indices $(\log (Q / K)$ as a function of temperature. Content of $\mathrm{Al}$ ions is fixed by equilibration with kaolinit

Fig. 9 Calculated statistics (median RMED, root-meansquare RMSE, standard deviation SDEV, and average MEAN) of values of SI at all temperatures

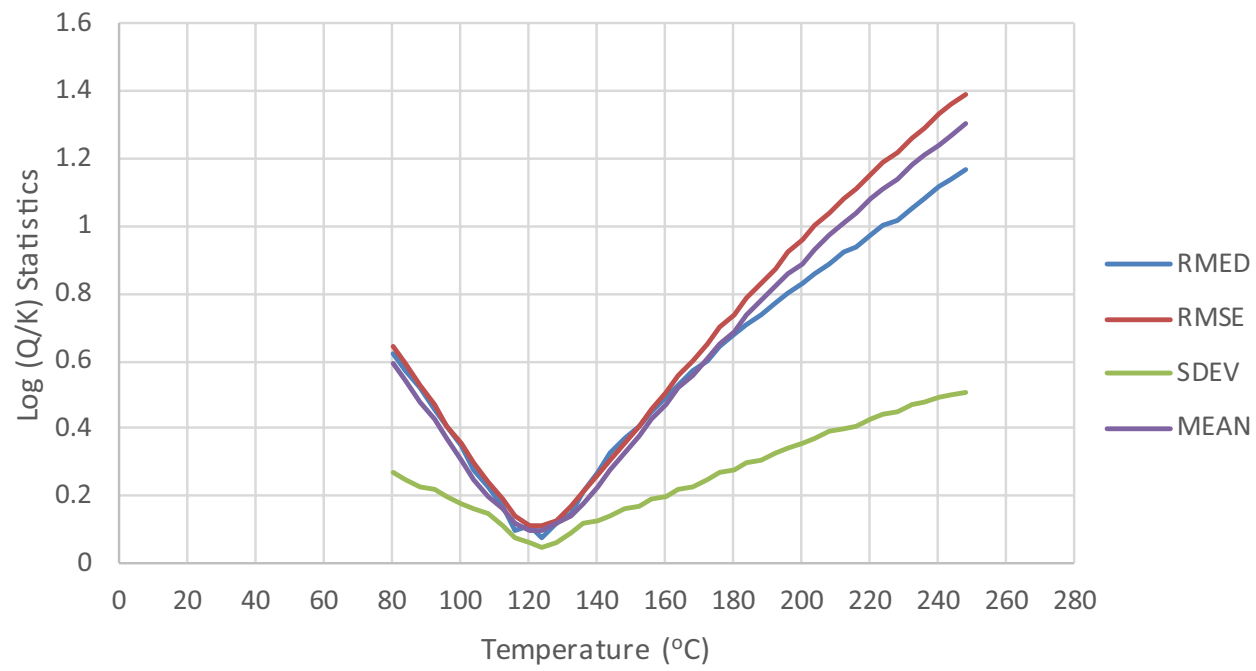


are indicative of inflow of water from one deep circulation system.

The conducted analysis of the character of changes in water temperature and intake discharge in various exploitation conditions has demonstrated that all the intakes of thermal therapeutic waters in Cieplice capture waters from the same fissure system. The exploitation of deep borehole $\mathrm{C}-1$, especially when involving high discharges, has a detrimental effect on the remaining intakes, which is manifested by decreasing water temperature and intake discharge.

The currently observed increase in the temperature of water flowing out of $\mathrm{C}-1$ borehole, accompanied by a drop in wellhead pressure, is related to the outflow of thermal waters of deeper circulation.

Open Access This article is licensed under a Creative Commons Attribution 4.0 International License, which permits use, sharing, adaptation, distribution and reproduction in any medium or format, as long as you give appropriate credit to the original author(s) and the source, provide a link to the Creative Commons licence, and indicate if changes were made. The images or other third party material in this article are included in the article's Creative Commons licence, unless indicated otherwise in a credit line to the material. If material is not included in the article's Creative Commons licence and your intended use is not permitted by statutory regulation or exceeds the permitted use, you will need to obtain permission directly from the copyright holder. To view a copy of this licence, visit http://creativecommons.org/licenses/by/4.0/.

\section{References}

Arnórsson S (2000) Isotopic and chemical techniques in geothermal exploration development and use. IAEA, Vienna

Borkowska M (1966) Petrography of the Karkonosze granite. Geologia Sudetica 1(2):7-104 (in Polish)

Ciężkowski W, Mroczkowska B (1985) Hydrogeochemical anomaly of Cieplice Śląskie Zdrój. Rocznik Pol Tow Geol 3-4(55):473-484 (in Polish)

Ciężkowski W, Gröninig M, Leśniak PM, Weise SM, Zuber A (1992) Origin and age of thermal waters in Cieplice Spa, Sudeten, inferred from isotope, chemical and noble gas data. J Hydrol 140:89-117

Ciężkowski W, Doktór S, Graniczny M, Kabat T, Kozłowski J, Liber E, Przylibski T, Teisseyre B, Wiśniewska M, Zuber A (1996) An attempt at determining recharge areas of therapeutic waters of infiltration origin in Poland on the basis of isotope research. App. 3. Therapeutic water deposit in Cieplice Śląskie Zdrój. Zakład Badawczo Usługowy "Zdroje" Wrocław (in Polish, unpublished)

Dobrzyński DR, Leśniak PM (2010) Two contrasting geothermal systems-towards the identification of geothermal reaction pattern and groundwater temperaturę, the Sudetes, Poland. In: Proceedings, XXXVIII IAH Congress, Poland, Kraków, September 12-17, 2010

Dowgiałło J (1973) Results of research into the isotopic composition of oxygen and hydrogen in groundwaters in southern Poland. Biuletyn Państwowego Instytutu Geologicznego 277(3):319-338 [in Polish]

Dowgiałło J (2002) The Sudetic Geothermal Region of Poland. Geothermics 31:343-359
Dowgiałło J (2007) Stae of waters surveying in the Sudetic Region and Prospects of their development. Tech Posz Geol 2:29-34 [in Polish]

Dowgiałło J, Fistek J (1998) Hydrogeological documentation of therapeutic waters in Jelenia Góra-Cieplice. PAN Instytut Nak Geologicznych Warszawa (in Polish, unpublished)

Dowgiałło J, Fistek J, Mierzejewski M (1989) Origin and circulation of thermal waters in the Jelenia Góra basin in light of structural and hydrogeochemical research. In: Problemy hydrogeologiczne południowo-zachodniej Polski. Prace Naukowe Instytutu Geotechniki Politechniki Wrocławskiej 58(29):315-359 (in Polish)

Dowgiałło J, Hałas S, Porowski A (2005) Isotope temperature indicators of thermal waters in south-western Poland. In: Proceedings World Geothermal Congress 2005, Antalya, Turkey, 24-29 April, 2005, pp 1-8

Duthou JL, Couturie JP, Mierzejewski MP, Pin C (1991) Age determination of the Karkonosze granite using isochrone $\mathrm{Rb}-\mathrm{Sr}$ whole rock method. Przeglad Geologiczny 2:75-79

Fistek J, Dowgiałło J (2003) Thermal waters of Cieplice Śląskie in light of geological and prospection works carried out in 196973 and 1997-98. In: Ciężkowski W, Wojewoda J, Żelaźniewicz A (eds) Sudety Zachodnie—od wendu do czwartorzędu. Wind Wrocław, 207-224 (in Polish)

Fournier RO (1977) Chemical geothermometers and mixing models for geothermal systems. Geothermics 5 (1-4):41-50

Fournier RO, Potter RW (1982) A revised and expanded silica (quartz) geothermometer. Geotherm Resour Council Bull 11(10):3-12

Fournier RO, Truesdell AH (1973) An empirical Na-K-Ca geothermometer for natural waters. Geochim Cosmochim Acta 37:1255-1275

Giggenbach WF (1988) Geothermal solute equilibria. Derivation of $\mathrm{Na}-\mathrm{K}-\mathrm{Mg}-\mathrm{Ca}$ geoindicators. Geochim Cosmochim Acta 52:2749-2765

Kiełczawa B, Liber-Makowska E (2018) Changes in selected quantitative and qualitative parameters of thermal therapeutic waters in Cieplice. Technika Poszukiwań Geologicznych 1:61-71 (in Polish)

Langmuir D (1997) Aqueous environmental geochemistry. Prentice Hall, Upper Saddle River, p 598

Leśniak PM, Nowak D (1993) Water-rock interaction In some mineral waters In the Sudetes, Poland: implications for chemical geothermometry. Ann Soc Geol Pol 63:101-118

Liber E (2008) Changes in the dynamics of thermal waters in Cieplice Śląskie Zdrój affecting exploitable groundwater resources. Technika Poszukiwań Geologicznych 47(1/2):17-38 (in Polish)

Liber-Makowska E, Ciężkowski W (2018) Appendix 1 to Hydrogeological documentation of therapeutic waters in Jelenia Góra-Cieplice. Politechnika Wrocławska (in Polish, unpublished)

Marheine D, Kachlik V, Maluski H, Potočka F, Żelaźniewicz A (2002) The 40Ar-39Ar ages fromthe West Sudetes (NE Bohemian massif): contains on the Variscan polyphase tcctonothermal development. In: Winchest J, Pharaoh T, Vernies J (eds) Paleozoic amalgamationof Central Europe, vol 201. Geological Society London Special Publications, London, pp 133-155

Marszałek H (2010) Hydrogeological zonation in the area of the Jelenia Góra basin (Western Sudetes). Biuletyn Państwowego Instytutu Geologicznego 440:87-100 (in Polish)

Mierzejewski MP (2005) The Karkonosze. Inanimate nature and man. Wydawnictwo Uniwersytetu Wrocławskiego (in Polish)

Neupane G, Mattson ED, Spycher N, Dobson PF, Conrad ME, Newell DL, Mcling TL, Wood TR, Cannon CJ, Atkinson TA, Brazell CW, Worthing WC (2017) Geochemical Evaluation of the Geothermal Resources of Camas Prairie, Idaho. In: Proceedings, 42nd workshop on geothermal reservoir engineering Stanford University, Stanford, California, February 13-15, 2017 
Pang ZH, Reed M (1998) Theoretical chemical thermometry on geothermal waters: problems and methods. Geochim Cosmochim Acta 62:1083-1091

Porowski A, Dowgialło J (2009) Application of selected geothermometers to exploration of low enthalpy thermal water: the Sudetic Geothermal Region in Poland. Environ Geol 58:1629-1638

Reed MH, Spycher N (1984) Calculation of $\mathrm{pH}$ and mineral equilibria in hydrothermal waters with application to geothermometry and studies of boiling and dilution. Geochim Cosmochim Acta 48:1479-1492

Spycher N, Peiffer L, Sonnenthal EL, Saldi G, Reed MH, Kennedy BM (2014) Integrated multicomponent solute geothermometry. Geothermics 51:113-123
Spycher N, Peiffer L, Finsterle S, Sonnenthal EL (2016) GeoT A computer program for multicomponent geothermometry and geochemical speciation. User's guide. Lawrence Berkeley National Laboratory, Berkeley

Szałamacha M (1964) Detailed geological map of the Sudetes 1:25,000 Sheet Jelenia Góra Zachód, Wydawnictwo Geologiczne Warszawa (in Polish)

Publisher's Note Springer Nature remains neutral with regard to jurisdictional claims in published maps and institutional affiliations. 